\title{
USPOREDBA ODUMIRANJA STABALA HRASTA LUŽNJAKA I POLJSKOG JASENA U ODNOSU NA EKOLOŠKU KONSTITUCIJU VRSTA
}

\section{COMPARISON BETWEEN TREE DIEBACK OF PEDUNCULATE OAK AND NARROW-LEAVED ASH IN RELATION TO ECOLOGICAL CONSTITUTION OF SPECIES}

\author{
Damir UGARKOVIĆ ${ }^{1}$ Kristina PLEŠA²
}

\begin{abstract}
Sažetak
Pojava odumiranja stabala hrasta lužnjaka (Quercus robur L.) i poljskog jasena(Fraxinus angustifolia Vahl) gospodarski je i ekološki problem. Čimbenici koji uzrokuju odumiranje stabala mogu biti biotski, stanišni i strukturni odnosno sastojinski.

Istraživanje je provedeno u gospodarskoj jedinici „Zelenika” u Posavini. Ciljevi ovog istraživanja bili su utvrditi prosječnu stopu promjene intenziteta odumiranja stabala hrasta lužnjaka i poljskog jasena, istražiti utjecaj stanišnih i strukturnih čimbenika na intenzitete odumiranja te usporediti intenzitete odumiranja hrasta lužnjaka i poljskog jasena prema dobnom razredu sastojina i mikroreljefu. Za analizu su korišteni podaci o klimi za meteorološku postaju Novska, vodostaju vodotoka Novska te podaci o razinama podzemne vode sa pjezometarske postaje „Zelenika“. Iz obrazaca O-2 Osnove gospodarenja, prikupljeni su podaci o volumenu odumrlih stabala hrasta lužnjaka i poljskog jasena te podaci o strukturnim čimbenicima.Intenziteti odumiranja izračunati su na temelju odnosa volumena odumrlih stabala po jedinici površine. S obzirom na prosječnu stopu promjene, intenziteti odumiranja hrasta lužnjaka i poljskog jasena se povećavaju. Najveći intenziteti odumiranja za obje šumske vrste su u sastojinama VI. dobnog razreda. Na osnovi provedenih istraživanja možemo zaključiti da klimatski, hidrološki i strukturni čimbenici imaju utjecaj na odumiranje hrasta lužnjaka i poljskog jasena. Hrast lužnjak osjetljiviji je na klimatske elemente u odnosu na poljski jasen.Pojava sušnih i izostanak kišnih razdoblja također značajno utječe na odumiranje. Smanjenje srednjegi minimalnog vodostaja vodotoka utječe na odumiranje hrasta lužnjaka, dok smanjenje maksimalnog vodostaja vodotoka utječe na odumiranje poljskog jasena. Na intenzitete odumiranja značajno utječe pad razine podzemne vode u dubljim slojevima pedosfere. Svi strukturni čimbenici utječu na odumiranje hrasta lužnjaka, dok na odumiranje poljskog jasena značajno utječe jedino povećanje obrasti i broja stabala u sastojini.
\end{abstract}

KLJUČNE RIJEČI: hrast lužnjak, poljski jasen, odumiranje, stanišni čimbenici, strukturni čimbenici

\section{UVOD}

\section{INTRODUCTION}

Odumiranje stabala je pojam koji se koristi za označavanje procesa koji u konačnici neminovno dovodi do smrti sta- bla. U većini slučajeva odumiranje je proces koji se već dogodio, pa je njegov rezultat odumrlo stablo (sušac), tj. ono stablo kod kojega su prekinute sve životne funkcije te je prešlo u kategoriju mrtvog dubećeg drva (Dekanić, 2014).

'Doc. dr. sc. Damir Ugarković, Šumarski fakultet Sveučilišta u Zagrebu, Zavod za ekologiju i uzgajanje šuma, Svetošimunska cesta 25, 10002 Zagreb, e-mail: damir.ugarkovic@gs.htnet.hr

${ }^{2}$ Kristina Pleša, mag. ing. silv., Mokrička ulica 18, 10290 Zaprešić, e-mail: plesa.kristina@gmail.com 
Odumiranjem se također može označiti i konačna faza smanjivanja vitaliteta do smrti kod onih stabala koja su prešla graničnu vrijednost vitaliteta (granicu nepovratnog oštećenja), kada se ne može doći do oporavka. Kod takvih stabala odumiranje je u tijeku, te je smrt neminovna kroz razdoblje od najviše nekoliko godina.

Budući da kod takvih stabala više ne postoji mogućnost oporavka, u fiziološkom, a i u šumskouzgojnom smislu, ova se stabla već mogu uvjetno smatrati odumrlima.Odumiruća stabla mogu se determinirati na temelju odgovarajućih indikatora vitaliteta (Prpić, 1996; Dobbertin, 2005). Neki od indikatora vitaliteta stabala su osutost krošanja, oblik krošanja, rast i prirast stabala, ishrana lišća i iglica, električni otpor u kambiju i ostali indikatori.

Čimbenici koji uzrokuju odumiranje stabala su biotski, sastojinski i stanišni (Vajda, 1968). Od biotskih čimbenika značajne su biljne bolesti, štetni kukci i divljač, od sastojinskih čimbenika značajni su način postanka sastojina, starost stabala i struktura sastojine, a od stanišnih čimbenika važno je djelovanje različitih prirodnih pojava (vjetar, mokar snijeg, ledena kiša, suša, dugotrajna poplava, grom), promjene ekoloških uvjeta (promjene hidroloških prilika, tj. snižavanja razina podzemne vode, promjena dinamike poplavne vode, zamočvarenja i isušivanja staništa, onečišćenja poplavne i oborinske vode) i nepovoljno djelovanje čovjeka (Durrant i Boswell, 2002). Onečišćenje zraka, pojava poplavnih voda u vegetacijskom razdoblju, te izostanak redovitih zimskih i proljetnih poplava uz istodobnu pojavu uzastopnih sušnih razdoblja ključni su stresni čimbenici, koji također nepovoljno utječu na nizinske šumske ekosustave (Prpić i dr. 1994; Vukelić i dr.1997; Prpić i Anić, 2000; Matić, 2000; Tikvić i dr. 2008). Odumiranje je posljedica kumulativnog i sinergetskog djelovanja različitih nepovoljnih čimbenika (Kozarac, 1897; Kovačević, 1928; Nenadić, 1940; Dekanić, 1972; Androić, 1975; Thomas i dr. 2002; Gaertig i dr. 2002; Prpić, 2003; Breda i dr. 2006). Čovjek sve više mijenja prirodnu ravnotežu šumskih ekosustava i uvelike utječe na negativno stanje nizinskih šuma

Ekološka konstitucija sadrži genotip, fenotip, stanište i konkurentsku sposobnost svojte (Ellenberg, 1956). Vrste šumskog drveća imaju različite zahtjeve prema staništu. Svaka vrsta ima svoju ekološku nišu. Analogno tomu, vrste šumskog drveća različito reagiraju na promjene stanišnih čimbenika, na stresove i u konačnici na odumiranje.

Zbog intenzivnoga propadanja i odumiranja stabala, što predstavaja sve veći problem u gospodarskim šumama, provode se tzv. sanitarne sječe (slučajni prihod) kako bi se smanjili gubici u gospodarenju šumama (Tikvić i dr. 2011). Volumen odumrlih stabala ili volumen stabala posječenih u sanitarnoj sječi najčešće se koristi za prikaz intenziteta odumiranja stabala, a može se koristiti i kao indikator zdravstvenog stanja šumskih sastojina (Capecki, 1981).
U posljednjih dvadesetak godina ntenziviralo se odumiranje stabala hrasta lužnjaka (Quercus robur L.) i poljskog jasena (Fraxinus angustifolia Vahl). U razdoblju od 1995. do 2007. godine u Hrvatskoj udio posječenih odumrlih stabala hrasta lužnjaka iznosio je od $35 \%$ od $40 \%$ ukupnoga etata hrasta lužnjaka (Matić, 2009). Prema Dubravcu i Dekaniću (2009), u razdoblju od 1996. do 2006. godine od ukupno posječenog drvnog volumena stabala hrasta lužnjaka u spačvanskim šumama, čak 58 \% odnosilo se na odumrla i oštećena stabla.

Odumiranje poljskog jasena zadnjih nekoliko godina na pojedinim lokalitetima u Republici Hrvatskoj stvara velike ekološke i gospodarske probleme. Pored abiotskih čimbenika, u procesu odumiranja poljskog jasena značajnu ulogu imaju i neki biotski čimbenici. Gljiva Chalara fraxinea, kao nova bolest potvrđena je na običnom i poljskom jasenu na širem području Hrvatske (Barić i dr. 2012).

Stoga su ciljevi ovog istraživanja izračunati i analizirati intenzitete odumiranja stabala hrasta lužnjaka i poljskog jasena prema volumenu, promjeni intenziteta odumiranja, utvrditi odnose između odumiranja hrasta lužnjaka i poljskog jasena, prikazati odumiranje stabala hrasta lužnjaka i poljskog jasena u odnosu na ekološku konstituciju vrsta tj. stanišne i strukturne čimbenike.

\section{MATERIJAL I METODE MATERIAL AND METHODS}

Istraživanja su provedena na području gospodarske jedinice „Zelenika“, Šumarija Stara Gradiška (Uprava Šuma Podružnica Nova Gradiška). Gospodarska jedinica smještena je uz trasu autoceste Zagreb-Lipovac, svega nekoliko kilometara jugoistočno od Novske. Ukupna površina gospodarske jedinice iznosi 3 364,53 ha. Površina uređajnog razreda hrasta lužnjaka iznosi 1 438,09 ha, a poljskog jasena 1911,50 ha. Drvna zaliha hrasta lužnjaka iznosi $454133 \mathrm{~m}^{3}$, a poljskog jasena $430974 \mathrm{~m}^{3}$. Srednja godišnja temperatura zraka za navedeno područje iznosi $11,2^{\circ} \mathrm{C}$. Prosječna godišnja količina oborina iznosi $919 \mathrm{~mm}$ (meteorološka postaja Novska, razdoblje 1981. - 2010.). Geološku podlogu ove gospodarske jedinice čini pretaloženi močvarni prapor na kojemu se razvija mineralno - močvarno tlo slabo kisele do neutralne reakcije. Prisutne pedosistematske jedinice su: (i) pseudoglej, (ii) močvarno glejno tlo ili euglej sa podtipovima poput hipogleja, epigleja i amfigleja te (iii) livadsko tlo ili semiglej sa podtipovima poput černozemno livadski semiglej, aluvijalno livadski podtip s moličnim ili okričnim humusnim horizontom te posmeđeno livadsko.

Za analizu odumiranja stabala u odnosu na stanišne čimbenike korišteni su podaci o klimatskim elementima i indeksima, vodostaju vodotoka Novska te podaci o razinama podzemne vode sa pjezometarske postaje „Zelenika“. Od 


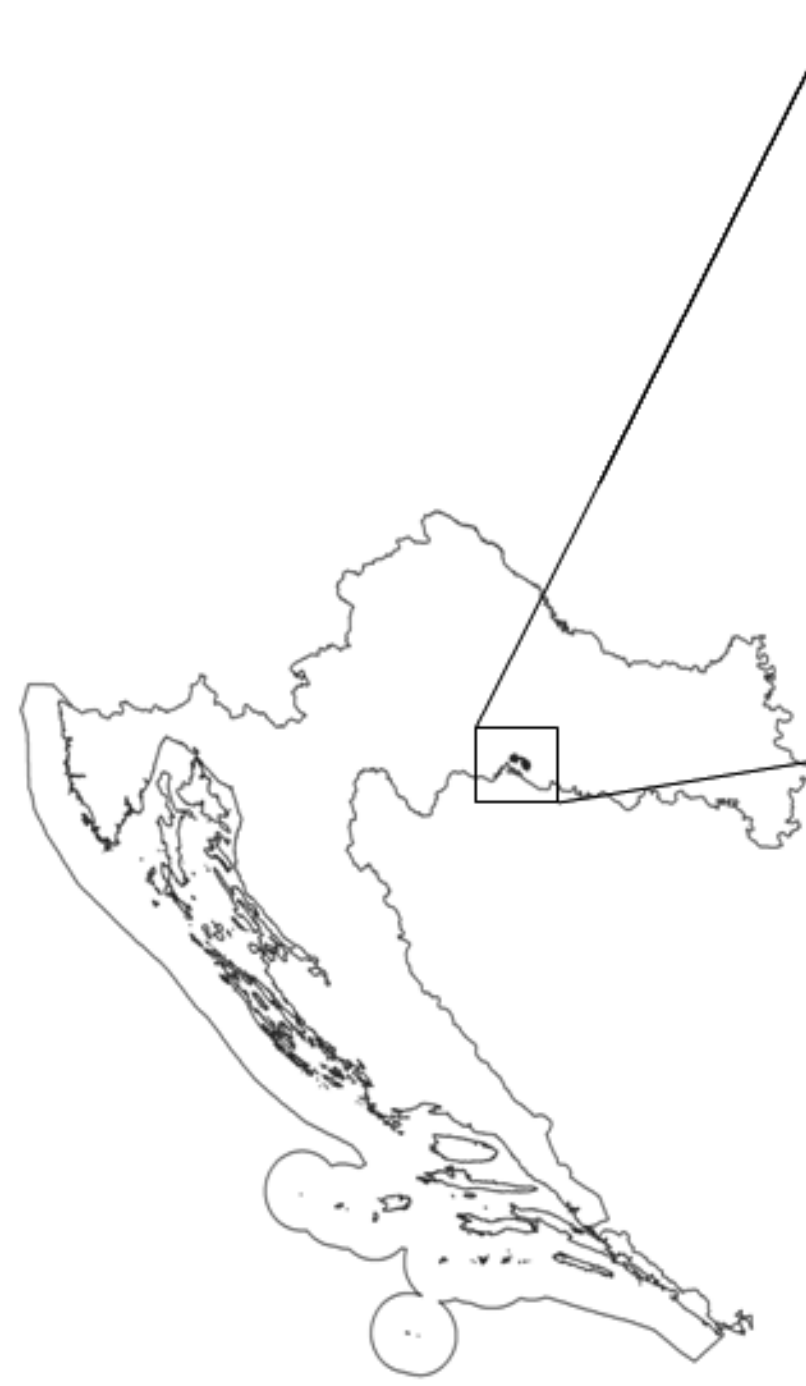

klimatskih elemenata korišteni su srednja godišnja temperatura zraka $\left({ }^{\circ} \mathrm{C}\right)$, srednja temperatura zraka najtoplijeg i najhladnijeg mjeseca u godini $\left({ }^{\circ} \mathrm{C}\right)$, srednje temperature zraka u proljeće i ljeto $\left({ }^{\circ} \mathrm{C}\right)$, maksimalne i minimalne temperature zraka u proljeće i ljeto $\left({ }^{\circ} \mathrm{C}\right)$, srednja godišnja količina oborina $(\mathrm{mm})$ te količina oborina u proljetnom i ljetnom razdoblju $(\mathrm{mm})$. Podaci o klimatskim elementima preuzeti su iz europske baze klimatskih podataka (Climate EU, http://eca.knmi.nl/) za meteorološku postaju Novska. Od klimatskih indeksa analizirane su vrijednosti indeksa manjka vlage CMD (prema engl. Climatic Moisture Deficit) $(\mathrm{mm})$ i vrijednosti referentne evapotranspiracije Eref ( $\mathrm{mm}$ ). Indeks manjka vlage predstavlja zbroj mjesečnih razlika između referentne evapotranspiracije i oborina, a referentna evapotranspiracija izračunata je prema metodi Hargreaves i Samani (1985). Nadalje, godišnji toplinsko vlažni indeks izračunat je prema formuli ((MAT+10)/(MAP/1000)), a ljetni toplinsko vlažni indeks izračunat je prema formuli ((MWMT)/(MSP/1000)), gdje je MAT - srednja godišnja temperatura zraka, MAP - godišnja količina oborina, MWMT - srednja temperatura zraka najtoplijeg mjeseca u godini i MSP - količina oborina u proljeće. Kontinentalnost (TD) izračunata je kao razlika najtoplijeg i najhladnijeg mjeseca u godini. Za analize vodostaja vodotoka Novska korišteni su podaci o maksimalnim, srednjim i minimalnim vodostajima za mjesece od travnja do rujna. Podzemna voda mjerena je u odsjecima5a i $9 \mathrm{~b}$ na četiri dubine (PJ 1 - 0,5 m, PJ 2 - 1,5 m, PJ 3 - 2,5 m, PJ 4 - 7 m). Sušne godine i sušna razdoblja te kišne godine i kišna razdoblja utvrđena su metodom percentila i na osnovi Walterovih klimatskih dijagrama.

Podaci o strukturnim čimbenicima, odnosno o strukturnim elementima šumskih sastojina prikupljeni su iz obrazaca O-2 Osnove gospodarenja gospodarskom jedinicom „Zelenika" (Anon. 1996, Anon. 2006) i to: starost sastojine (godine), broj stabala (N/ha), obrast, temeljnica ( $\left.\mathrm{m}^{2} / \mathrm{ha}\right)$, volumen sastojine $\left(\mathrm{m}^{3} / \mathrm{ha}\right)$ te godišnji tečajni prirast $\left(\mathrm{m}^{3} / \mathrm{ha}\right)$. $\mathrm{Na}$ osnovi podatka o šumskoj zajednici (obrazac O-2), sastojine su grupirane u tipove mikroreljefa: greda, niza i bara. Također, iz obrazaca O-2 Osnove gospodarenja, prikupljeni su i podaci o volumenu odumrlih stabala hrasta lužnjaka i poljskog jasena na razini svih odsjeka gospodarske jedinice 


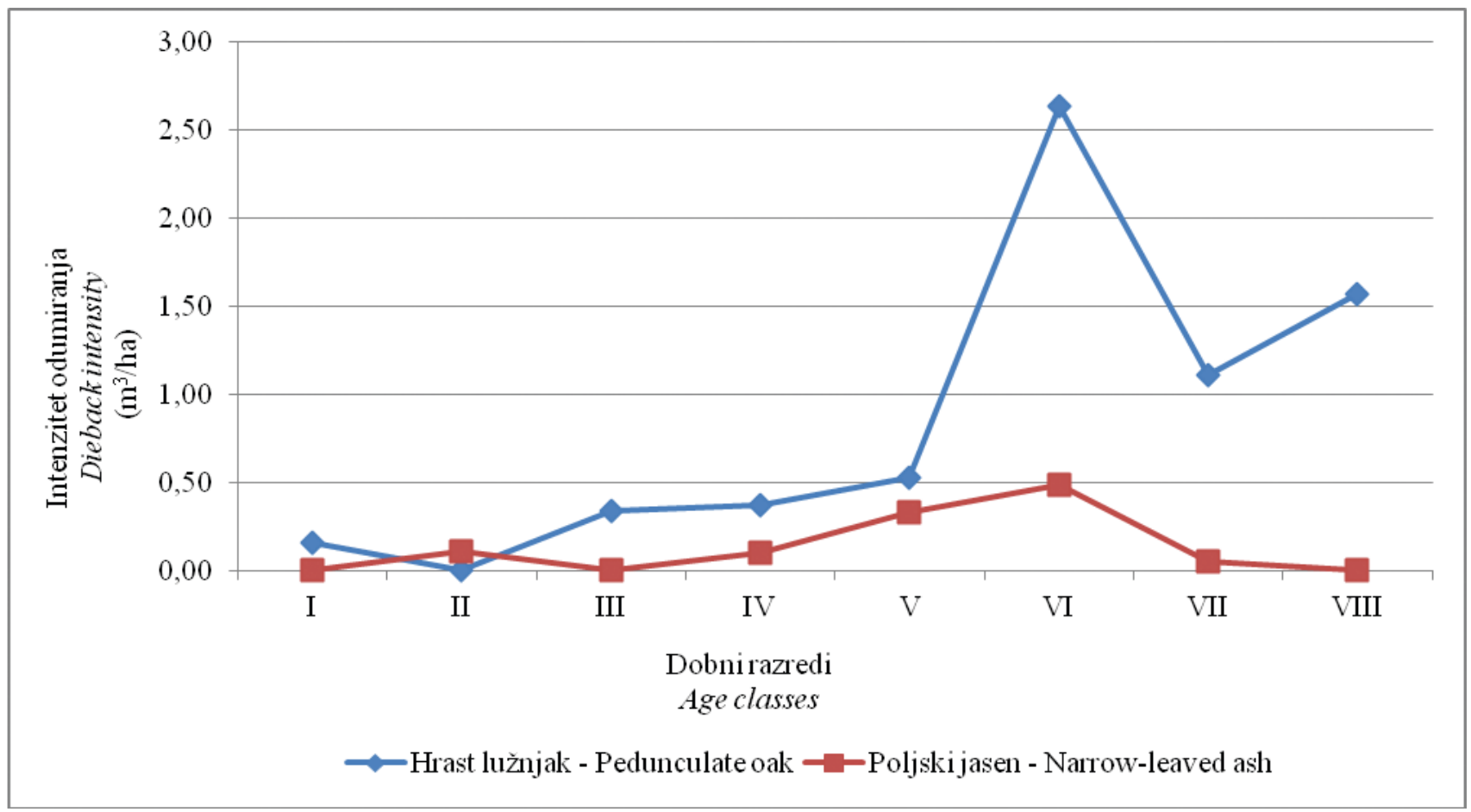

Slika 2. Prosječni intenziteti odumiranja $\left(\mathrm{m}^{3} / \mathrm{ha}\right.$ ) hrasta lužnjaka i poljskog jasena po dobnim razredima

Figure 2. Average dieback intensity $\left(\mathrm{m}^{3} / \mathrm{ha}\right)$ of penduculate oak and narrow-leaved ash according to age class

( $\mathrm{N}=124$ sanitarne sječe). Svi navedeni podaci prikupljeni su za razdoblje od 1996. do 2014. godine. Intenzitet odumiranja stabala prikazan je u apsolutnom obliku kao $\mathrm{m}^{3} / \mathrm{ha}$ (Siwecki i Ufnalski, 1998).

Prosječna stopa promjene $(\hat{S})$ intenziteta odumiranja za vremenski niz od 1996. do 2014. godine izračunata je preko verižnih indeksa (geometrijske sredine verižnih indeksa), a izražena je u postocima prema formuli

$$
\breve{S}=100 \cdot\left(\sqrt[n-1]{\frac{y n}{y 1}}-1\right)
$$

gdje je vrijednost promjene za prvu $\left(\mathrm{y}_{1}\right)$ i zadnju $\left(\mathrm{y}_{\mathrm{n}}\right)$ vremensku točku promatranog razdoblja $t_{1}, \ldots . ., t_{n}$.

Klimatski podaci obrađeni su u programu KlimaSoft 2.1. (Monachus, 2004). Statistička obrada podataka (deskriptivna statistika, jednosmjerne analize varijance ANOVA, Spearman rank R korelacija) provedena je u statističkom programu Statistica 7.1. (StatSoft, Inc. 2007).

\section{REZULTATI}

\section{RESULTS}

U razdoblju od 1994. do 2014. godine, prosječna stopa promjena $(\hat{S})$ intenziteta odumiranja hrasta lužnjaka iznosila je $8 \%$ godišnje, a za poljski jasen $15 \%$ godišnje. S obzirom na dobne razrede najmanji intenziteti odumiranja za obje vrste imale su sastojine I i II. dobnog razreda, a najveći intenziteti odumiranja bili su u VI. dobnom razredu (slika 2).
S obzirom na dobne razrede tj. starost sastojina utvrdili smo statistički značajne razlike u odumiranju hrasta lužnjaka između VI. i III. dobnog razreda $(\mathrm{p}=0,006)$, VI. i IV. dobnog razreda $(\mathrm{p}=0,002)$, VI. i V. dobnog razreda $(\mathrm{p}=0,001)$, te VI. i VII. dobnog razreda $(\mathrm{p}=0,034)$. Analizom varijance (ANOVA) utvrđeno je da nema značajnih razlika u odumiranju poljskog jasena s obzirom na dobne razrede tj. starost sastojina $(\mathrm{p}=0,93)$.

Prema rezultatima prikazanim u tablicama 1 i 2 prosječni intenziteti odumiranja hrasta lužnjaka na mikroreljefu greda i niza bili su značajno veći u odnosu na intenzitete odumiranja poljskog jasena. Maksimalni intenziteti odumiranja hrasta lužnjaka bili su također veći u odnosu na

Tablica 1. Deskriptivna statistika intenziteta odumiranja $\left(\mathrm{m}^{3} / \mathrm{ha}\right)$ stabala hrasta lužnjaka i poljskog jasena

Table 1. Descriptive statistic of dieback intensity $\left(\mathrm{m}^{3} / \mathrm{ha}\right)$ on pedunculate oak and narrow- leaved ash trees

\begin{tabular}{lcc} 
& \multicolumn{1}{c}{$\begin{array}{c}\text { Vrsta drveća } \\
\text { Tree species }\end{array}$} \\
\cline { 2 - 3 } $\begin{array}{l}\text { Tip mikroreljefa } \\
\text { Microrelief type }\end{array}$ & \multicolumn{1}{c}{$\begin{array}{c}\text { Prosjek (min - max) } \\
\text { Average }(\text { min }- \text { max })\end{array}$} \\
\cline { 2 - 3 } & $\begin{array}{c}\text { Hrast lužnjak } \\
\text { Pedunculate oak }\end{array}$ & $\begin{array}{c}\text { Poljski jasen } \\
\text { Narrow-leaved ash }\end{array}$ \\
\hline $\begin{array}{l}\text { Greda } \\
\text { Microplateaus }\end{array}$ & $4,18(0,00-34,07)$ & $0,17(0,00-0,79)$ \\
\hline $\begin{array}{l}\text { Niza } \\
\text { Microdepressions }\end{array}$ & $2,90(0,00-70,16)$ & $1,18(0,04-7,69)$ \\
\hline $\begin{array}{l}\text { Bara } \\
\text { Wet microdepressions }\end{array}$ & $5,10(0,37-21,18)$ & $5,72(0,56-28,68)$
\end{tabular}


poljski jasen natipovima mikroreljefa greda i niza. Nisu utvrđene značajne razlike $u$ intenzitetu odumiranja hrasta lužnjaka i poljskog jasena za tip mikroreljefa bara. Prosječni i maksimalni intenzitet odumiranja poljskog jasena u tipu mikroreljefa bara bio je veći u odnosu na intenzitet odumiranja hrasta lužnjaka.

Nisu utvrđene značajne razlike u intenzitetu odumiranja stabala hrasta lužnjaka prema tri tipa mikroreljefa. Intenziteti odumiranja poljskog jasena značajno su se povećavali od tipa mikroreljefa greda, preko mikroreljefa niza do mikroreljefa bara. Najveći prosječni intenziteti odumiranja hrasta lužnjaka i poljskog jasena bili su u mikroreljefu bara (tablica 3).

Korelacijskom analizom utvrđena je značajna i pozitivna veza između odumiranja hrasta lužnjaka na tipu mikroreljefa greda i poljskog jasena na tipu mikroreljefa bara, te između odumiranja hrasta lužnjaka i poljskog jasena u tipu mikroreljefa niza (tablica 4).

Prema rezultatima prikazanim u tablici 5, od klimatskih čimbenika najveći utjecaj na odumiranje hrasta lužnjaka

Tablica 2. Usporedba intenziteta odumiranja ( $\mathrm{m}^{3} / \mathrm{ha}$ ) hrasta lužnjaka i poljskog jasena

Table 2. Comparison of dieback intensity $\left(\mathrm{m}^{3} / \mathrm{ha}\right.$ ) between pedunculate oak and narrow-leaved ash

\begin{tabular}{lcc} 
& \multicolumn{1}{c}{$\begin{array}{c}\text { Vrsta drveća } \\
\text { Tree species }\end{array}$} \\
\cline { 2 - 3 } $\begin{array}{l}\text { Tip mikroreljefa } \\
\text { Microrelief type }\end{array}$ & \multicolumn{1}{c}{$\begin{array}{c}\text { Prosjek } \pm \text { Standardna devijacija } \\
\text { Average } \pm \text { Standard deviation }\end{array}$} \\
\cline { 2 - 3 } & $\begin{array}{c}\text { Hrast lužnjak } \\
\text { Pedunculate oak }\end{array}$ & $\begin{array}{c}\text { Poljski jasen } \\
\text { Narrow-leaved ash }\end{array}$ \\
\hline $\begin{array}{l}\text { Greda } \\
\text { Microplateaus }\end{array}$ & $4,18 \pm 6,33^{\mathrm{a}}$ & $0,17 \pm 0,24^{\mathrm{b}}$ \\
\hline $\begin{array}{l}\text { Niza } \\
\text { Microdepressions }\end{array}$ & $2,90 \pm 5,90^{\mathrm{a}}$ & $1,18 \pm 1,58^{\mathrm{b}}$ \\
\hline $\begin{array}{l}\text { Bara } \\
\text { Wet microdepressions }\end{array}$ & $5,10 \pm 6,31$ & $5,72 \pm 8,24$ \\
\hline
\end{tabular}

a,b Vrijednosti unutar reda označena različitim slovom, značajno se razlikuju $(p<0,05)$ $a, b$ Values within the row marked with different letter differ significantly $(p<0.05)$

Tablica 3. Usporedba intenziteta odumiranja $\left(\mathrm{m}^{3} / \mathrm{ha}\right.$ ) stabala hrasta lužnjaka i poljskog jasena prema mikroreljefu

Table 3. Comparison of dieback intensity $\left(\mathrm{m}^{3} / \mathrm{ha}\right)$ of pedunculate oak and narrow-leaved ash according to microrelief

\begin{tabular}{lccc} 
& \multicolumn{3}{c}{$\begin{array}{c}\text { Tip mikroreljefa } \\
\text { Microrelief type }\end{array}$} \\
\cline { 2 - 4 } $\begin{array}{l}\text { Vrsta drveća } \\
\text { Tree species }\end{array}$ & $\begin{array}{c}\text { Greda } \\
\text { Microplateaus }\end{array}$ & $\begin{array}{c}\text { Mizaro- } \\
\text { depressions }\end{array}$ & $\begin{array}{c}\text { Wara } \\
\text { Wepressions } \\
\text { depron }\end{array}$ \\
$\begin{array}{l}\text { Hrast lužnjak } \\
\text { Pedunculate oak }\end{array}$ & $4,18 \pm 6,33$ & $2,90 \pm 5,90$ & $5,10 \pm 6,31$ \\
$\begin{array}{l}\text { Poljski jasen } \\
\text { Narrow-leaved ash }\end{array}$ & $0,17 \pm 0,24^{\mathrm{a}}$ & $1,18 \pm 1,58^{\mathrm{b}}$ & $5,72 \pm 8,24^{\mathrm{c}}$
\end{tabular}

a,b,c Vrijednosti unutar reda označena različitim slovom, značajno se razlikuju $(p<0,05)$

$a, b, c$ Values within the row marked with different letter differ significantly $(p<0.05)$
Tablica 4. Spearman korelacija intenziteta odumiranja stabala $\left(\mathrm{m}^{3} / \mathrm{ha}\right)$ prema vrstama šumskog drveća i mikroreljefa

Table 4. Spearman correlation of tree dieback intensity $\left(\mathrm{m}^{3} / \mathrm{ha}\right)$ according to forest tree species and microrelief

\begin{tabular}{|c|c|c|c|c|c|c|}
\hline \begin{tabular}{|l|} 
Varijable \\
Variables
\end{tabular} & GL & $\mathrm{NL}$ & $\mathrm{BL}$ & GJ & NJ & BJ \\
\hline $\mathrm{GL}$ & 1,00 & - & - & - & - & - \\
\hline NL & 0,13 & 1,00 & - & - & - & - \\
\hline $\mathrm{BL}$ & $-0,03$ & 0,38 & 1,00 & - & - & - \\
\hline GJ & 0,01 & $-0,30$ & $-0,46$ & 1,00 & - & - \\
\hline NJ & 0,10 & $0,43^{*}$ & 0,26 & $-0,24$ & 1,00 & - \\
\hline BJ & $0,68^{*}$ & 0,13 & $-0,11$ & 0,01 & $-0,09$ & 1,00 \\
\hline
\end{tabular}

* Signifikantno na razni $p<0,05$

* Significant difference for $\mathrm{p}<0.05$

$\mathrm{GL}$ - greda (lužnjak) - microplateaus (oak), NL - niza (lužnjak) - microdepressions (oak), BL - bara (lužnjak) - wet microdepressions (oak), GJ - greda (jasen) - microplateaus (ash), $\mathrm{NJ}$ - niza (jasen) - microdepressions (ash), BJ - bara (jasen) - wet microdepressions (ash)

Tablica 5. Spearman korelacija intenziteta odumiranja stabala i klimatskih elemenata,indeksa

Table 5. Spearman correlation of tree dieback intensity and climate elements, indices

$\begin{array}{lcc}\begin{array}{l}\text { Klimatski elementi/ } \\ \text { indeksi }\end{array} & \begin{array}{c}\text { Intenziteti odumiranja } \\ \text { hrasta lužnjaka } \\ \text { Climate elements/ } \\ \text { indices }\end{array} & \begin{array}{c}\text { Intenziteti odumiranja } \\ \text { poljskog jasena } \\ \text { dieback intensity }\end{array} \\ \text { TMAXsp } & 0,02 & \begin{array}{c}\text { Narrow-leaf ash } \\ \text { dieback intensity }\end{array} \\ \text { TMAXsm } & 0,15^{*} & 0,20 \\ \text { TMINsp } & 0,08 & 0,24 \\ \text { TMINsm } & -0,09 & 0,18 \\ \text { TAVsp } & 0,02 & -0,02 \\ \text { TAVsm } & -0,12 & 0,20 \\ \text { PPTsp } & -0,14^{*} & -0,16 \\ \text { PPTsm } & 0,07 & -0,15 \\ \text { MAT } & 0,09 & 0,21 \\ \text { TD } & 0,05 & 0,11 \\ \text { MAP } & -0,25^{*} & 0,20 \\ \text { MSP } & -0,17^{*} & -0,25^{*} \\ \text { AHM } & 0,24^{*} & -0,07 \\ \text { SHM } & 0,20^{*} & 0,23 \\ \text { EREF } & 0,14^{*} & 0,11 \\ \text { CMD } & 0,22^{*} & 0,18^{*} \\ \text { S } & 0,29^{*} & 0,11 \\ \text { K } & -0,11^{*} & 0,36^{*} \\ \text { * } & & -0,33^{*}\end{array}$

* Signifikantno na razni $p<0,05$

${ }^{*}$ Significant difference for $p<0.05$

TMAXsp - srednja maksimalna temperatura u proljeće $\left({ }^{\circ} \mathrm{C}\right)$ - spring mean maximum temperature, TMAXsm - srednja maksimalna temperatura u ljeto $\left({ }^{\circ} \mathrm{C}\right)$ - summer mean maximum temperature, TMINsp - srednja minimalna temperatura u proljeće $\left({ }^{\circ} \mathrm{C}\right)$ - spring mean minimum temperature, TMINsm - srednja minimalna temperatura u ljeto $\left({ }^{\circ} \mathrm{C}\right)$ - summer mean minimum temperature, TAVsp - srednja proljetna temperatura zraka $\left({ }^{\circ} \mathrm{C}\right)$ - spring mean temperature, TAVsm - srednja ljetna temperatura zraka $\left({ }^{\circ} \mathrm{C}\right)$ - summer mean temperature,PPTsp - proljetna količina oborina $(\mathrm{mm})$ - spring precipitation, PPTsm - ljetna količina oborina $(\mathrm{mm})$ - summer precipitation, MAT- srednja godišnja temperatura $\left({ }^{\circ} \mathrm{C}\right)$ - mean annual temperature,TD - kontinentalnost $\left({ }^{\circ} \mathrm{C}\right)$ - continentality, MAP - srednja godišnja količina oborina $(\mathrm{mm})$ - mean annual precipitation, MSP - srednja ljetna količina oborina $(\mathrm{mm})$ - mean summer precipitation,AHM - godišnji toplinsko-vlažni indeks - annual heat:moisture index, SHM - ljetni toplinsko-vlažni indeks - summer heat:moisture index, EREF referentna evapotranspiracija $(\mathrm{mm})$ - Hargreaves reference evapotranspiration,CMD - deficit vlažnosti prema Hargreavesu - Hargreaves climatic moisture deficit, S sušno razdoblje - drought period, $\mathrm{K}$ - kišno razdoblje - rain period 
imalo je smanjenje godišnje količine oborina $\left(-0,25^{*}\right)$ te povećanje deficita vlažnosti $\left(0,22^{\star}\right)$. Najmanje, ali ipak statistički značajne korelacije između odumiranja stabala hrasta lužnjaka i klimatskih čimbenika, bile su smanjenje proljetnih količina oborina $\left(-0,14^{*}\right)$ i povećanje iznosa evapotranspiracije $\left(0,14^{*}\right)$. Od svih promatranih klimatskih čimbenika na odumiranje poljskog jasena jedino je značajno utjecalo smanjenje godišnje količine oborina $\left(-0,25^{\star}\right)$ i povećanje evapotranspiracija $\left(0,18^{\star}\right)$.Utvrđena je statistički značajna veza između klimatskih pojava, kao što su sušna i kišna razdoblja te intenziteta odumiranja hrasta lužnjaka i poljskog jasena. Pojava sušnih razdoblja i izostanak kišnih razdoblja značajno su utjecali na odumiranje hrasta lužnjaka i poljskog jasena (tablica 5).

Smanjenje srednjeg i minimalnog vodostaja $\left(-0,14^{*}\right.$ i $\left.-0,17^{*}\right)$ značajno je utjecalo na odumiranje hrasta lužnjaka. Smanjenje maksimalnog vodostaja $\left(-0,16^{*}\right)$ i minimalnog vodostaja $\left(-0,11^{\star}\right)$ značajno je utjecalo na odumiranje poljskog jasena (tablica 6).

Tablica 6. Spearman korelacija intenziteta odumiranja stabala i vodostaja vodotoka Novska

Table 6. Speraman correlation between tree dieback intensity and water level of Novska watercourse

$\begin{array}{lcc}\begin{array}{l}\text { Vodostaji } \\ \text { vodotoka }\end{array} & \begin{array}{c}\text { Intenziteti odumiranja } \\ \text { hrasta lužnjaka } \\ \text { Wedunculate oak }\end{array} & \begin{array}{c}\text { Intenziteti odumiranja } \\ \text { poljskog jasena } \\ \text { Narrow-leaved ash } \\ \text { watercourse }\end{array} \\ \text { dieback intensity } & \begin{array}{c}\text { dieback intensity } \\ \text { Max. }\end{array} & -0,16^{*} \\ \text { Sred. } & -0,14^{*} & -0,07 \\ \text { Min. } & -0,17^{*} & -0,11^{*}\end{array}$

* Signifikantno na razni $p<0,05$

*Significant difference for $\mathrm{p}<0.05$

Max - maksimalni vodostaji - maximal water level, Sred - srednjaci vodostaja average water level, Min - minimalni vodostaji - minimal water level

Tablica 7. Spearman korelacija intenziteta odumiranja stabala i razine podzemne vode

Table 7. Spearman correlation between tree dieback intensity and level of groundwater

$\begin{array}{lcc}\text { Pjezometarske postaje } & \begin{array}{c}\text { Intenziteti odumiranja } \\ \text { hrasta lužnjaka } \\ \text { Pedunculate oak } \\ \text { Piezometric stations }\end{array} & \begin{array}{c}\text { Intenziteta odumiranja } \\ \text { poljskog jasena } \\ \text { Narrow-leaved ash } \\ \text { dieback intensity }\end{array} \\ \text { PJ 1 5A } & -0,09 & -0,03 \\ \text { PJ 2 5A } & -0,10 & 0,00 \\ \text { PJ 3 5A } & -0,12 & 0,07 \\ \text { PJ 4 5A } & -0,17^{*} & -0,10^{*} \\ \text { PJ 1 9B } & -0,11 & -0,12^{*} \\ \text { PJ 2 9B } & -0,09 & -0,06 \\ \text { PJ 3 9B } & -0,14 & -0,02 \\ \text { PJ 4 9B } & -0,13 & -0,15 \\ \text { * Signifikantno na razni p }<0,05 & \\ \text { *Significant difference for p }<0.05 & \\ \text { PJ 1-4 (5A) - pjezometarska postaja na gredi - piezometric station on micropla- } \\ \text { teaus, PJ 1-4 (9B) - pjezometarska postaja u nizi - piezometric station on micro- } \\ \text { depressions }\end{array}$

Tablica 8. Spearman korelacija intenziteta odumiranja stabala i strukturnih elemenata

Table 8. Spearman correlation between tree dieback intensity and structural elements

\begin{tabular}{lcc} 
Strukturni elementi & $\begin{array}{c}\text { Intenziteti odumiranja } \\
\text { hrasta lužnjaka } \\
\text { Pedunculate oak } \\
\text { dieback intensity }\end{array}$ & $\begin{array}{c}\text { Intenziteti odumiranja } \\
\text { poljskog jasena } \\
\text { Narrow-leaved ash } \\
\text { dieback intensity }\end{array}$ \\
\hline Obrast - Stocking & $-0,13^{*}$ & $0,28^{*}$ \\
Starost - Age & $0,19^{*}$ & $-0,01$ \\
N & $0,12^{*}$ & $0,23^{*}$ \\
G & $0,38^{*}$ & 0,17 \\
DZ & $0,41^{*}$ & 0,13 \\
g.t.p. & $0,21^{*}$ & 0,14
\end{tabular}

* Signifikantno na razni $p<0,05$

* Significant difference for $p<0.05$

$\mathrm{N}$ - broj stabala - number of trees, $\mathrm{G}$ - temeljnica $\left(\mathrm{m}^{2} / \mathrm{ha}\right)$ - basal area, DZ - drvna zaliha $\left(\mathrm{m}^{3} / \mathrm{ha}\right)$ - growing stock, g,t,p - godišnji tečajni prirast $\left(\mathrm{m}^{3} / \mathrm{ha}\right)$ - annual increment

Smanjenje razine podzemne vode na gredi $\left(-0,17^{*}\right)$ značajnojeutjecalo na odumiranje hrasta lužnjaka, dok je smanjenje razine podzemne vode na gredi $\left(-0,10^{*}\right)$ i nizi $\left(-0,12^{*}\right)$ utjecalo na odumiranje poljskog jasena (tablica 7 ).

Intenziteti odumiranja hrasta lužnjaka značajno su korelirali sa svim istraživanim strukturnim čimbenicima. Najveća korelacija utvrđena je između odumiranja hrasta lužnjaka i drvne zalihe sastojine $\left(0,41^{*}\right)$, a najmanja između odumiranja hrasta lužnjaka i obrasti $\left(-0,13^{\star}\right)$. Utvrđena je pozitivna i značajna korelacija između odumiranja poljskog jasena i obrasti $\left(0,28^{\star}\right)$ te broja stabala u sastojini $\left(0,23^{\star}\right)$ (tablica 8).

\section{RASPRAVA DISCUSSION}

Prosječna stopa promjene intenziteta odumiranja bila je veća kod poljskog jasena u usporedbi s hrastom lužnjakom. Pretpostavljamo da je ono povezano ponajprije s biotskim čimbenikom uzroka odumiranja, gljive Chalara fraxinea čija prisutnost je potvrđena 2012. godine na području Republike Hrvatske. Prema rezultatima ovog istraživanja, intenziteti odumiranja stabala hrasta lužnjaka povećavali su se sa starošću sastojina i bili su veći u sastojinama V., VI. i VII. dobnog razreda. Međutim za poljski jasen to nije slučaj. Nema statistički značajnih razlika u odumiranju poljskog jasena s obzirom na dobne razrede, iako je najveći intenzitet odumiranja također bio u sastojinama VI. dobnog razreda (slika 1).

Tikvić i dr. (2006) su utvrdili maksimalne vrijednosti odumiranja hrasta lužnjaka po jedinici površine i preko $100 \mathrm{~m}^{3} /$ ha, što se može smatrati katastrofalnim odumiranjem stabala. Prema našim istraživanjima maksimalni intenziteti odumiranja bili su od $21,18 \mathrm{~m}^{3} /$ ha do $70,16 \mathrm{~m}^{3} / \mathrm{ha}$. U prilog 
manjim intenzitetima odumiranja stabala hrasta lužnjaka na predmetnom području istraživanja idu i istraživanja Tikvića i dr. (2011) koji zaključuju da je na području Posavine najpovoljnije stanje vitalnosti sastojina utvrđeno u gospodarskoj jedinici „Zelenika“ koja se nalazi izvan izravnog utjecaja voda rijeke Save i umjetnoga vodotoka Strug.

König (1911) opisujući odumiranje hrasta lužnjaka u kotaru Sisak s obzirom na mikroreljef, poplave, brštenje gusjenica i pepelnicu, tvrdi da je odumiranje na gredama slabije, a Manojlović (1924) i Jošovac (1924) nalaze najintenzivnije odumiranje u nižim predjelima sa stagnirajućom vodom i oko bara. Na području g.j. „Zelenika“ također smo utvrdili najveće odumiranje hrasta lužnjaka u mikroreljefu bara.

Prema istraživanjima Dubravca i Dekanića (2009) nisu ustanovljene statistički značajne razlike u odumiranju stabala hrasta lužnjaka među odsjecima triju biljnih zajednica, dok je u prosjeku najveći ukupni intenzitet sječe suhih i odumirućih (3B) stabala utvrđen na gredi, a u nizi nešto niži. Prema ovom provedenom istraživanju u g.j."Zelenika" također nisu ustanovljene statistički značajne razlike za intenzitete odumiranja hrasta lužnjaka u tri tipa mikroreljefa. Na osnovi provedenog istraživanja, najveće prosječno odumiranje hrasta lužnjaka bilo je u mikroreljefu bara, zatim greda, a najmanje na mikroreljefu niza. Intenziteti odumiranja poljskog jasena bili su najveći u mikroreljefu bara, a najmanji na mikroreljefu greda. Što se tiče korelacije odumiranja hrasta lužnjaka i poljskog jasena s obzirom na mikroreljef, utvrđena je veza između odumiranja hrasta lužnjaka na gredi i poljskog jasena u bari, te hrasta lužnjaka i poljskog jasena u nizi. Ovi rezultati su i očekivani s obzirom na postotno učešće ovih dviju vrsta u drvnom volumenu sastojina s obzirom na tipove mikroreljefa i njihove ekološke niše s obzirom na mikroreljef. S obzirom na ekološku konstituciju vrsta, mikroreljef greda predstavlja optimum za hrast lužnjak, a bara za poljski jasen, dok se u mikroreljefu niza preklapaju ekološke niše ovih dviju vrsta.

S obzirom na istraživane klimatske elemente i indekse, hrast lužnjak više je klimatski osjetljiva vrsta u odnosu na poljski jasen. Od svih istraživanih klimatskih elemenata i indeksa na odumiranje poljskog jasena jedino je značajno utjecalo smanjene godišnje količine oborina i povećanje evapotranspiracije. Poljski jasen kao pionirska vrsta šumskog drveća ima šire ekološke valencije za pojedine stanišne čimbenika u odnosu na hrast lužnjak. Stoga je i očekivano da je pojava njegovog odumiranja ovisna o manjem broju klimatskih elemenata i indeksa u odnosu na hrast lužnjak.

Učestale sušne godine značajno utječu na odumiranje ove dvije vrste koje su s obzirom na ekološke zahtjeve prema vodi higrofiti. Prema ovim rezultatima istraživanja, poljski jasen je vrsta osjetljivija na sušu u odnosu na hrast lužnjak. On je euritermna vrsta koja podnosi visoke i niske tempe- rature zraka, ali kao izrazitiji higrofit zahtjeva veću količinu dostupne vode odnosno vlage u tlu. Iz tog razloga odumiranje ove vrste ovisi i o povećanju evapotranspiracije, smanjenju maksimalnih vodostaja vodotoka, odnosno o izostanku kišnog razdoblja i poplavne vode u ekosustavu.

Što se tiče kišnog razdoblja, na odumiranje stabala hrasta lužnjaka i poljskog jasena utječe izostanak kišnih razdoblja. Također poljski jasen je osjetljiviji na izostanak kišnih razdoblja u odnosu na hrast lužnjak. Dugotrajna kišna razdoblja u konačnici rezultiraju i visokim riječnim vodostajima i velikom količinom poplavne vode (Ugarković i dr. 2016). Dugotrajne poplave hrast lužnjak ne može podnijeti za razliku od poljskog jasena koji je higrofilnija vrsta šumskog drveća (Drvodelić i dr. 2016). Također važno je napomenuti da poljski jasen ne može uspijevati u močvarnim prilikama kada voda stoji na tlu tijekom čitavoga vegetacijskog razdoblja (Prpić i dr. 2005).Predviđene klimatske promjene na području nizinske Hrvatske vjerojatno će uzrokovati povećanje vrijednosti temperatura zraka i smanjenje količina oborina (DHMZ, 2009). Trenutno stanje hidroloških prilika, znatno izmijenjenih u zadnjih nekoliko desetljeća kroz pojavu jakih suša, postaju sve neprikladnije za opstojnost nizinskih šuma s obzirom na zahtjeve za vodu i ovisnost nizinskih vrsta o podzemnoj vodi (Vrbek i dr. 2011.).

Smanjenje srednjih i minimalnih vodostaja vodotoka utjecalo je na povećano odumiranje hrasta lužnjaka, dok je smanjenje maksimalnih i minimalnih vodostaja utjecalo na odumiranje poljskog jasena. Maksimalne vodostaje vodotoka vežemo uz pojave poplava, a dugotrajne poplave su nešto što hrast lužnjak kao vrsta ne podnosi. Stoga su i korelacije za vodostaje vodotoka koje smo dobili za hrast lužnjak manje u odnosu na poljski jasen. Smanjenje razine podzemne vode značajno je utjecalo na odumiranje i hrasta lužnjaka i poljskog jasena.

Hrastu lužnjaku i poljskom jasenu potrebna je velika količina vode za transpiraciju. Ta količina vode najčešće prelazi količinu oborina u vegetacijskom razdoblju. Zbog te potrebe ove dvije vrste moraju imati na raspolaganju dodatnu vodu tj. podzemnu vodu (Prpić, 1996).

Podzemna voda neophodna je za rast, razvoj i opstojnost nizinskih vrsta. Istraživanja u Mađarskoj (Móricz, 2010) pokazuju da je učešće konzumacije podzemne vode kod hrasta lužnjaka $58 \%$ od iznosa ukupne transpiracije. Za vrijeme suše, učešće konzumacije podzemne vode značajno je veće i iznosilo je $66 \%$ od ukupne transpiracije. Prema istom autoru opskrba vodom od podzemne vode manje je značajna za vrijeme vlažnog odnosno kišnog razdoblja. Iz tog razloga je i utjecaj sušnih razdoblja na odumiranje ove dvije vrste bio veći u odnosu na izostanak kišnih razdoblja u ovim nizinskim šumama na području g.j. „Zelenika“.

Hrast lužnjak ima duboko korijenje s žilom srčanicom, dokpoljski jasen ima plitku korijensku mrežu. Stoga je na odu- 
miranje ovih vrsta šumskog drveća utjecao i pad razine podzemne vode $i$ to u dubljim slojevima pedosfere na gredi za hrast lužnjak i plićim slojevima pedosfere u nizi za poljski jasen.

Odumiranje stabala hrasta lužnjaka bilo je veće u starijim sastojinama, te u sastojinama s manjom obrasti, većim brojem stabala, temeljnicom i drvnom zalihom. Kako je odumiranje hrasta lužnjaka već dugo prisutno na području Republike Hrvatske, pa i šire, uslijed odumiranja stabala dolazi do smanjenja obrasti sastojina stoga je i negativna korelacija koju smo dobili za obrast bila očekivana. Kod poljskog jasena intenziteti odumiranja bili su veći u sastojinama s većim brojem stabala i većom obrasti. Dio odumiranja stabala poljskog jasena možemo pripisati međuvrsnoj i unutarvrsnoj konkurenciji.

Poznato je da postoji antagonizam između susjednih jasenovih stabala, da korijenje stabla poljskog jasena fiziološki ne srašćuje, te je stoga u sastojinama poljskog jasena s većim brojem stabala po jedinici površine izraženija unutarvrsna konkurencija koja rezultira i odumiranjem. Prema Dubravcu i Dekaniću (2009) ne može se generalizirati kada se govori o ulozi starosti sastojine u procesu odumiranja hrasta lužnjaka, jer starost sastojine vjerojatno samo pojačava ostale negativne čimbenike u onim sastojinama u kojima su ti čimbenici već prisutni. Međutim u našem istraživanju za poljski jasen to nije slučaj. Nismo ustanovili korelaciju između odumiranja stabala poljskog jasena i starosti sastojina.

\section{ZAKLJUČCI}

\section{CONCLUSIONS}

S obzirom na prosječnu stopu promjene, povećavali su se intenziteti odumiranja hrasta lužnjaka i poljskog jasena. Najveći intenziteti odumiranja za obje šumske vrste bili su u sastojinama VI. dobnog razreda. Usporedbom intenziteta odumiranja hrasta lužnjaka i poljskog jasena prema mikroreljefu utvrđeno je značajno veće odumiranje hrasta lužnjaka u odnosu na poljski jasen u dva tipa mikroreljefa, greda i niza. U bari nisu utvrđene značajne razlike u odumiranju hrasta lužnjaka i poljskog jasena. S obzirom na mikroreljef ne postoje značajne razlike u intenzitetima odumiranja hrasta lužnjaka između tri tipa mikroreljefa, dok se odumiranje poljskog jasena statistički značajno povećavalo od mikroreljefa greda prema mikroreljefu bara. $\mathrm{Na}$ osnovi provedenih istraživanja možemo zaključiti da su klimatski, hidrološki i strukturni čimbenici imali utjecaj na odumiranje hrasta lužnjaka i poljskog jasena. Hrast lužnjak osjetljiviji je na klimu i klimatske promjene u odnosu na poljski jasen. Na odumiranje hrasta lužnjaka značajno je utjecao veći broj klimatskih elemenata i indeksa kao što su maksimalna ljetna i srednja godišnja temperatura zraka, količina oborina u proljeće i godišnja količina oborina, godišnji i ljetni toplinsko vlažni indeks, evapotranspiracija i deficit vlažnosti klime. Na odumiranje poljskog jasena utječe jedino smanjenje godišnje količine oborina i povećanje evapotranspiracije. Učestalost sušnih i izostanak kišnih razdoblja također značajno utječu na odumiranje hrasta lužnjaka i poljskog jasena, s time da su korelacije veće za poljski jasen. Smanjenje srednjeg i minimalnog vodostaja vodotoka utjecalo je na odumiranje hrasta lužnjaka, dok smanjenje maksimalnog vodostaja vodotoka utjecalo je na odumiranje poljskog jasena. Na intenzitete odumiranja obje istraživane vrste značajno je utjecao pad razine podzemne vode, pogotovo u dubljim slojevima pedosfere. Svi istraživani strukturni čimbenici utjecali suna odumiranje hrasta lužnjaka, dok na odumiranje poljskog jasena značajno je utjecalo jedino povećanje obrasti i broja stabala u sastojini.

\section{LITERATURA}

REFERENCES

- Anon. 1996: Osnova gospodarenja gospodarskom jedinicom „Zelenika”, važnost od 01.01.1996.do 31.12.2005. „Hrvatske šume" d. o. o. Zagreb, str. 120.

- Anon. 2006: Osnova gospodarenja gospodarskom jedinicom „Zelenika”, važnost od 01.01.2006.do 31.12.2015. „Hrvatske šume" d. o. o. Zagreb, str. 125.

- Androić, M., 1975: Prethodni rezultati timskog istraživanja uzroka sušenja hrasta u slavonskim šumama, U: M. Androić (ur.), Simpozij Sto godina znanstvenog i organiziranog pristupa šumarstvu jugoistočne Slavonije, JAZU Centar za znanstveni rad Vinkovci, 59.-78., Zagreb

- Barić, L., M. Županić, M. Pernek, D. Diminić, 2012: Prvi nalaz patogene gljive Chalara fraxinea u Hrvatskoj - novog uzročnika odumiranja jasena (Fraxinus spp,), Šumarski list, Vol. (9-10): 461.-469., Zagreb

- Breda, N., R. Huc, A. Grainer, E. Dreyer, 2006: Temperate forest tree and stands under severe drought: a review of ecophysiological responses, adaptation processes and long-term consequences, Annals od Forest Science, Vol. (63): 625.-644.

- Capecki, Z., 1981: The rules of prediction of vulnerability and protection of spruce forests against insect pests following after damage caused by wind and rime, Prace Inst Bad Leśn, Vol. (584): 3. -44

- Climate EU, http://eca.knmi.nl/

- Dekanić, I., 1972: Utvrđivanje najpogodnijih vrsta drveća i metoda obnove opustošenih površina sušenjem hrasta lužnjaka (Quercus robur L,), Šumarski list, Vol. (4-6): 119.-127., Zagreb

- Dekanić, S., 2014: Morfološka i dendrokronološka analiza oštećenih stabala hrasta lužnjaka (Quercus robur $\mathrm{L}$,) u starim sastojinama spačvanskog bazena, Doktorska disertacija, Šumarski fakultet Zagreb, (S.; str. = 258.)

- DHMZ, 2009: Peto nacionalno izvješće Republike Hrvatske prema Okvirnoj konvenciji Ujedinjenih naroda o promjeni klime (UNFCCC), Državni hidrometeorološki zavod Republike Hrvatske, Zagreb.

- Drvodelić, D., D. Ugarković, M. Oršanić, V. Paulić, 2016: The Impact of Drought, Normal Watering and Substrate Saturation 
on the Morphological and Physiological Condition of Container Seedlings of Narrow-Leaved Ash (Fraxinus angustifolia Vahl). South-East European Forestry 7 (2): early view. DOI: http:// dx.doi.org/10.15177/seefor.16-11

- Dobbertin, M., 2005: Tree growth as indicator of tree vitality and of tree reaction to environmental stress: a review,Eurpean Journal of Forest Research, Vol.(124):319.-333.

- Dubravac, T., S. Dekanić, 2009: Struktura i dinamika sječe suhih i odumirućih stabala hrasta lužnjaka u Spačvanskom bazenu od 1996. do 2006. godine, Šumarski list, Vol. (7-8): 391.-405., Zagreb

- Durrant, D., R. Boswell, 2002: Comparison of crown density assessments on trees within the stand and on ride edges within the forest, Forest Ecology and Management, Vol. (1-3): 1.-6.

- Ellenberg, H., 1956: Aufgaben und Methoden der Vegetationskunde, Eugen Ulmer Verlag, str. 156.,Stuttgart

- Gaertig, T., H. Schack - Kirchner, E.E. Hildebrand, K. V. Wilpert, 2002: The impact of soil aeration on oak decline in southwestern Germany, Forest Ecology and Management, Vol. (159): 15.-25.

- Hargreaves, G.H., Z.A. Samani, 1985: Reference crop evapotranspiration from temperature, Applied Engineering in Agriculture 1, Vol. (2): 96.-99.

- Jošovac, A., 1924: Sušenje hrastovih sastojina šumske uprave u Dragancu, Šumarski list, Vol. (12): 639.-642., Zagreb

- Kovačević, Ž., 1928: Sušenje hrastova u Posavini sa entomološkobiološkog gledišta, Šumarski List, Vol. (4): 182.-185., Zagreb

- Kozarac, J., 1897: Šumogojstveni i drvotržni aforizmi, crpljeni na temelju prodaje

- posavskih hrastovih šuma u zadnjem desetgodištu 1887.-1896., Šumarski list, Vol. (7), Zagreb

- König, J., 1911 : Sušenje hrastika, Šumarski list, Vol. (10-11): 385.-422., Zagreb

- Manojlović, P., 1924: Sušenje hrastovih šuma (Hrast lužnjak), Šumarski list, Vol. (10): 502.-505., Zagreb

- Matić, S., 2000: Oak forests (Quercus sp.) in Croatia, Glasnik za šumske pokuse, Vol. (37): 5.-13., Zagreb

- Matić, S., 2009: Gospodarenje šumama hrasta lužnjaka (Quercus robur L.) u promijenjenim stanišnim i strukturnim uvjetima,Zbornik radova sa znanstvenog skupa Šume hrasta lužnjaka u promijenjenim stanišnim i gospodarskim uvjetima, HAZU, 1.-22.,Zagreb

- Monachus 2004: KlimaSoft 2.1., www.mrg.hr

- Móricz, N., 2010: Water balance Study of a Groundwater-dependent Oak Forests, Acta Silvatica \& Lignaria Hungarica, Vol. (6): 49.-66.

- Nenadić, Đ., 1940: O posljedicama sušenja hrastovih šuma Gradiške imovne općine,Glasnik za šumske pokuse, Vol. (7), 1.-29., Zagreb

- Prpić, B., Z. Seletković, G. Žnidarić, 1994: Ekološki i biološki uzroci propadanja stabala hrasta lužnjaka (Quercus robur L.) u nizinskoj šumi Turopoljski lug, Glasnik za šumske pokuse, Vol. (30): 193.-222., Zagreb

- Prpić, B., 1996: Propadanje šuma hrasta lužnjaka, U: D. Klepac (ur.), Hrast lužnjak u Hrvatskoj, Hrvatska akademija znanosti i umjetnosti, „Hrvatske šume“ d.o.o., 273.-298., Zagreb

- Prpić, B., I. Anić, 2000: The role of climatic and hydraulic operations in the stability of the pedunculate oak (Quercus robur L.) stands in Croatia, Glasnik za šumske pokuse, Vol. (37): 229.239., Zagreb

- Prpić, B., 2003: Utjecaj tehničkih zahvata u prostoru na nizinske šume, Šumarski list, Vol. (5-6): 230.-235., Zagreb

- Prpić, B., Z. Seletković, I. Tikvić, 2005: Ekološka konstitucija vrsta drveća iz poplavnih šuma.U: S. Matić (ur.), Poplavne šume u Hrvatskoj, Akademija šumarskih znanosti,147.-160., Zagreb

- Siwecki, R., K.Ufnalski, 1998: Review of oak stand decline with special reference to the role of drought in Poland, European Journal of Forest Pathology, Vol. (28): 99.-112.

- StatSoft, Inc. 2007.Electronic Statistics Textbook. Tulsa, OK, USA, http://www.statsoft.com/textbook/

- Thomas, F.M., R. Blank, G. Hartmann, 2002: Abiotic and biotic factors and their interactions as causes of oak decline in Central Europe, Forest Pathology, Vol. (32): 277.-307.

- Tikvić, I., Z. Seletković, D. Ugarković, Z. Balta, 2006: Procjena propadanja šuma hrasta lužnjaka na temelju indeksa odumiranja stabala, Glasnik za šumske pokuse, Posebno izdanje, Vol. (5): 117.-127., Zagreb

- Tikvić, I., I. Anić, Z. Seletković, D. Ugarković, J. Gašpar, 2008: Vitalnost i odumiranje stabala hrasta lužnjaka kao pokazatelj promjene stabilnosti nizinskih šuma, Zbornik sažetaka sa znanstvenog skupa Šume hrasta lužnjaka u promijenjenim stanišnim gospodarskim uvjetima, HAZU, 16. -17., Zagreb

- Tikvić, I., D. Ugarković, J. Gašpar, 2011: Prostorna analiza odumiranja stabala hrasta lužnjaka (Quercus robur L.) za potrebe adaptivnog gospodarenja šumskim ekosustavima u Hrvatskoj, Croatian Journal of Forest Engeneering, Vol. (32): 43.- 56., Zagreb

- Ugarković, D., I. Tikvić, D. Balta, M. Vucelja, 2016: Dynamics, hydrological relations and pollution of precipitation and flood waters i forest ecosystem, U: I. Radojčić Redovniković (ur.), Natural resources green technology \& sustainable development, Faculty of Food Technology and Biotechnology, str. 116., Zagreb

- Vajda, Z., 1968: Naučno istraživačke studije o sušenju hrastika, Šumarski list, Vol. (2-3): 122.-142., Zagreb

- Vrbek, B., I. Pilaš, N.Pernar, 2011: Observed Climate Change in Croatia and its impact on hydrology of lowlands, Forest Management and Water Cycle, Springer, 141.-162., Heidelberg, London, New York

- Vukelić, J., I. Tikvić, Z. Seletković, D. Baričević, 1997: Dieback of Pedunculate oak from the ecological-vegetative aspect, IUFRO međunarodna konferencija Advances in Research in Intermediate Oak stands, 213.-222., Freiburg

\section{Summary}

The pedunculate oak (Quercus robur L.) and narrow-leaved ash (Fraxinus angustifolia Vahl) tree dieback phenomenon presents an economic as well as ecologic problem. Factors that cause tree dieback can be biotic, biotopic (within habitat) and structural (within stand).In managedforests, the volume of dead trees or volume 
of trees cut in a sanitation harvests are most often used to show the intensity of tree dieback, and may also be used as an indicator of the stands condition (Capecki, 1981).Every species has its own ecological niche. Forest tree species have varying reactions to changes in environmental factors, to stress and ultimately to dying. The study was conducted in „Zelenika” management unit in Posavina.The aims of the study were to establish pedunculate oak and narrow-leaved ash tree dieback dynamics, to research the influence of biotopic and structural factors on dieback intensity and to compare dieback intensities according to the stand age class and microrelief. For analysis were climatic data for Novska meteorological station, water level data of Novska watercourse, and groundwater level data from „Zelenika” piezometric station were used. Dry years and dry periods, and wet years and wet periods, were determined using the percentile method and the Walter climate diagrams.

Growing volume of withered pedunculate oak and ash trees, as well as structural factors data(stand structure elements) were collected from the O-2 form of the Forest management plan. Dieback intensities were calculated on the basis of growing volume of the withered trees per area unit ratio. The intensity of tree death was shown in absolute numbers, as $\mathrm{m}^{3} /$ ha (Siwecki et al. 1998).

Considering the average change rate, dieback intensities of pedunculate oak and narrow-leaved ash tree are increasing. The highest dieback intensities for both forest species were found in the VI age class (Figure 2). On the basis of the conducted research, it can be concluded that climatic, hydrological and structural factors influence pedunculate oak and narrow-leaved ash tree dieback.

Pedunculate oak is more sensitive to climatic elements in comparison to narrow-leaved ash tree. Frequent dry years significantly affected the dying of these two species, which can both be considered hydrophytes in terms of their ecological demand for water. The results of this study showed that narrow-leaved ash was more vulnerable to drought than pedunculate oak.

Drought and rain periods also significantly influence tree dieback (table 5). The effect of dry periods on the dieback of these two species was greater in relation to the lack of wet periods in these lowland forests. The decrease of mid and minimal water levels of watercourse influenced pedunculate oak dieback, while adecrease of maximum watercourse water levels influenced narrow-leaved ash tree dieback (table 6). Groundwater level decrease in deeper layers of pedosphere had asignificant influence on tree dieback intensities (table 7). It was revealed that all structural factors influence pedunculate oak dieback, while narrow-leaved ash tree dieback was influenced only by stocking and tree number increase in a stand (table 8). The dieback of pedunculate oak was higher in older stands. No correlation was detected between the dieback of narrow-leafed ash and stand age.

KEY WORDS: pedunculate oak, narrow-leaved ash tree, dieback, biotopic factors, structural factors 